\title{
THE HISTOLOGICAL STUDY OF THE EFFECT OF GELS WITH SILVER NANOPARTICLES AND GLUCOSAMINE ON PURULENT WOUND HEALING
}

\author{
L.Bulyga, Ya.Butko, Yu.Laryanovska \\ National University of Pharmacy \\ Key words: festering wound; gels; silver nanoparticles; glucosamine, histology
}

\begin{abstract}
The search for new drugs to treat purulent wounds is one of the urgent problems of modern medicine. Most local wound healing drugs at the pharmaceutical market of Ukraine do not meet all modern medical and biological requirements for effective treatment of the wound process, and there is a need in expansion of their range. Modern developments related to the use of silver nanoparticles for treatment of wounds have several advantages, such as the multilevel antibacterial effect, delayed resistance, low toxicity, anti-inflammatory and reparative properties. The aim of our work was the histological study of the effect of gels with silver nanoparticles and glucosamine on healing the skin with a purulent necrotic wound in rats. The results have shown that the gels with glucosamine or silver nanoparticles and their combination applied to animals have better histological parameters of recovery of damaged tissues than those of the reference drug - "Dermazin" cream. A newly formed tissue has the most complete character in the wound of animals treated with the sample of the gel with silver nanoparticles and glucosamine. It confirms the rationality of the combination proposed and the absence of antagonism between the active ingredients. Therefore, for further pharmacological studies the combined gel containing glucosamine and silver nanoparticles is promising in order to develop a local drug of a new generation to treat infectious surface wounds.
\end{abstract}

Treatment of purulent wounds is one of the problems of modern medicine. It is connected with the numerous domestic, industrial and military injuries, traffic accidents, natural disasters, as well as the increasing number of postoperative complications $[2,4]$. According to medical statistic approximately $30 \%$ of patients have postoperative infectious complications [2].

In the treatment of wounds and infectious complications, along with surgical treatment and systemic therapy, the local treatment is also important. Most local wound healing drugs at the pharmaceutical market of Ukraine do not meet all modern medical and biological requirements for effective treatment of the wound process, and there is a need in expansion of their range. For example, antibiotics included in the majority of wound healing drugs adversely affect granulation (especially tetracycline; aminoglycosides (gentamycin) and chloramphenicol to a lesser extent); they are characterized by the rapid development of resistance, inhibit the local flora. Among antiseptics iodopiron and silver nitrate (18 and 25\%, respectively) slightly inhibit development of granulation. Chlorhexidine has the most negative effect on the reparative processes in the wound $[1,3,6,7]$.

The use of achievements of nanotechnologies opens up prospects for optimizing reactive changes and reparative processes that develop in the site of the tissue damage. Modern developments related to the use of silver nanoparticles for treatment of wounds have several advantages, such as the multilevel antibacterial effect, delayed resistance, low toxicity, anti-inflammatory and reparative properties $[2,7,8,9]$.
The Department of Industrial Technology of Drugs of the NUPh has developed the experimental samples of gels containing silver nanoparticles (obtained by electron-beam evaporation at the Ye.O.Paton Electric Welding Institute of the NAS of Ukraine) stabilized by polyvinylpyrrolidone (PVP) and/or glucosamine hydrochloride.

The data of the previous studies of silver nanoparticles confirm the presence of the antimicrobial effect against gram-positive and gram-negative microorganisms. Glucosamine hydrochloride is a natural structural material for the organism and possesses the anti-inflammatory, antioxidant, immunomodulating, analgesic, wound healing, and even antimicrobial properties, and PVP has the detoxication properties $[3,5]$.

The aim of our work was the histological study of the effect of gels with silver nanoparticles and glucosamine on healing the skin with a purulent necrotic wound in rats.

\section{Materials and Methods}

The study of pharmacological properties of the gels with the different composition (the gel with glucosamine, the gel with silver nanoparticles and a combined gel with silver nanoparticles and glucosamine) was carried out on the model of purulent necrotic wounds (Table). This model allows studying several types of the pharmacological activity for the local drugs for treating wounds, such as antimicrobial, anti-inflammatory, reparative.

"Dermazin" cream (manufacturer - Salyutas Pharma GmbH, Germany, batch SR0680) containing 1\% of silver sulfadiazine and indicated for the treatment of purulent wounds was chosen as a reference drug [2]. 
Table

The composition of the gels containing silver nanoparticles

\begin{tabular}{|l|l|}
\hline Drug & \multicolumn{1}{|c|}{ The main active substances } \\
\hline Gel 1 & Glucosamine (1.0\%) + PVP (2.0\%) \\
\hline Gel 2 & PVP (Ag 0.164\%-0.1\%) + PVP (2.0\%) \\
\hline Gel 3 & $\begin{array}{l}\text { Glucosamine (1.0\%) + PVP (Ag 0.164\% - 0.1\%) + } \\
\text { PVP (up to 2.0\%) }\end{array}$ \\
\hline
\end{tabular}

In the experiment 40 male albino rats weighing $260-300 \mathrm{~g}$ were used. They were divided into 8 groups: Group $1-$ intact control (IC); Group 2 - peak of pathology (PP, rats were decapitated after the wound festering); Group 3 control pathology (CP); Group 4, 5, 6, 7 - rats treated with gels 1, 2, 3, 4; Group 8 - animals treated with the reference drug. The skin necrosis was caused by introduction of $1.0 \mathrm{ml}$ of $10 \%$ calcium chloride solution subcutaneously. In 3 days after injection the formation of necrosis foci was observed, then microbial contamination of wounds was carried out (P. aeruginosa - ATCC-27853 and S. aureus - ATCC-29213). Treatment with the gels with nanosilver/reference drug under study was carried out within 9 days from the third day after infection with a causative agent (after the occurrence of pus on the ulcer surface). For the histological study all of the above samples of the skin were selected as follows: in natural healing - on day 3 (with pathology development) and on day 11 after infection, when treating with the gels or the reference drug - on day 11 after infection. Samples were cut from the skin defect site and the neighbouring areas of the healthy skin. All tissue material was fixed in the neutral $10 \%$ formalin solution and poured in paraffin. Sections were made on a sliding microtome and stained with haematoxylin and eosin $[2,4]$. The micro- slides were examined under a Micros 400 microscope. Microphotography of microscopic images was made by a Nicon Col Pix 4500 digital camera. The pictures were processed on a Pentium $2.4 \mathrm{GHz}$ PC using Nicon View 5. The quality assessment was performed by such healing characteristics as the size and depth of the defect, the condition of a newly formed tissue in it (the presence and depth of layers, severity of fibroblast proliferation, the signs of fibre formation), the level of epithelialisation.

\section{Results and Discussion}

The results of histological studies have shown that on day 3 after infection of necrotic wounds a widespread deep defect on the rat's skin is seen on microslides. The multilayered sanious haemorrhagic necrotic crust tightly covers the surface of the defect. The defect is filled with a mixture of modified destructive residues of connective tissue fibres of the dermis and muscle fibres that are densely infiltrated, and the foci of festering are observed. There is also the cellular infiltrate in the subcutaneous adipose tissue, the layer of muscle fibres and the underlying loose fibrous tissue. The process of inflammation is advanced. There are visible "petrified" fibres, giant cells, thrombosed blood vessels in the defect (Fig. $1 \mathrm{a}, \mathrm{b}, \mathrm{c}$ ).

In the control pathology group on 11 day after infection a purulent necrotic wound has little changes in depth and size (Fig. 1 d, e, f, g). The crust on the surface is less dense, sometimes with visible stratified remnants. The diffused cellular infiltration of the subcutaneous fat tissue, the layer of muscle fibres and the underlying fibrous tissue is preserved. The sites of necrosis are seen. At the edge of the defect hypertrophy of the epidermis is preserved, and there is edema of the papillary dermis. The marginal epithelisation is absent.

After 9-day treatment with the gel containing glucosamine (gel 1) there are no skin defects in $40 \%$ of rats. The epidermal layer is completely restored. In the site of the dermis a loose fibrous tissue with a moderate cellular content is seen. In $20 \%$ of the animals there
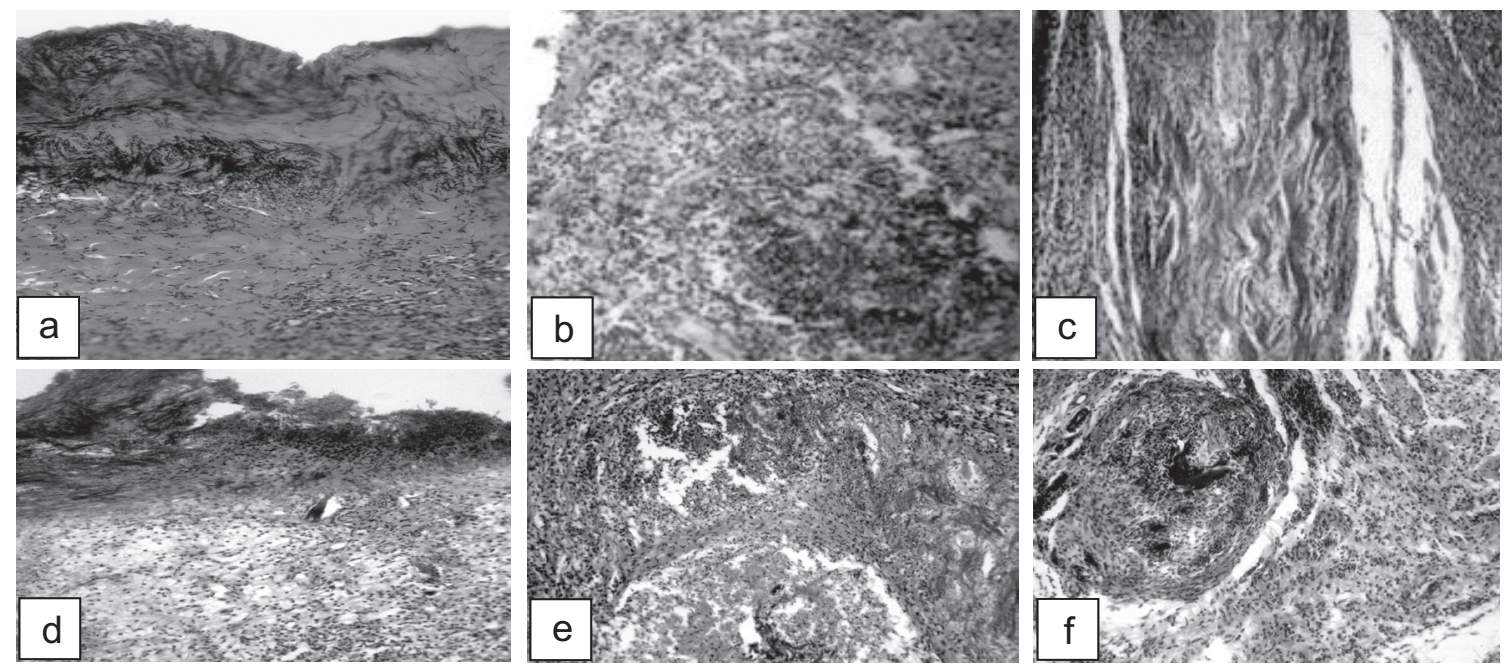

Fig. 1. The histological study of purulent necrotic wounds in the control pathology group. Notes: 1) On day 3 after infection, a - a multilayer crust on the surface of ulcer, necrosis of the connective tissue fibres of the dermis ( $x 100) ; b$ - the abundant inflammatory infiltrate of the subcutaneous fat and muscle tissue (x 200); c - destructive fibres with the altered tinctorial properties. Haematoxylin-eosin $\times 250,200$. 2) On day 11 after infection; $d$ - under the stratified crust there is a visible collagen matrix in the state of protein coagulation; $e-$ sites of tissue detritus in the underlying tissues; $f$ - the site with "petrified" remnants of fibres. 

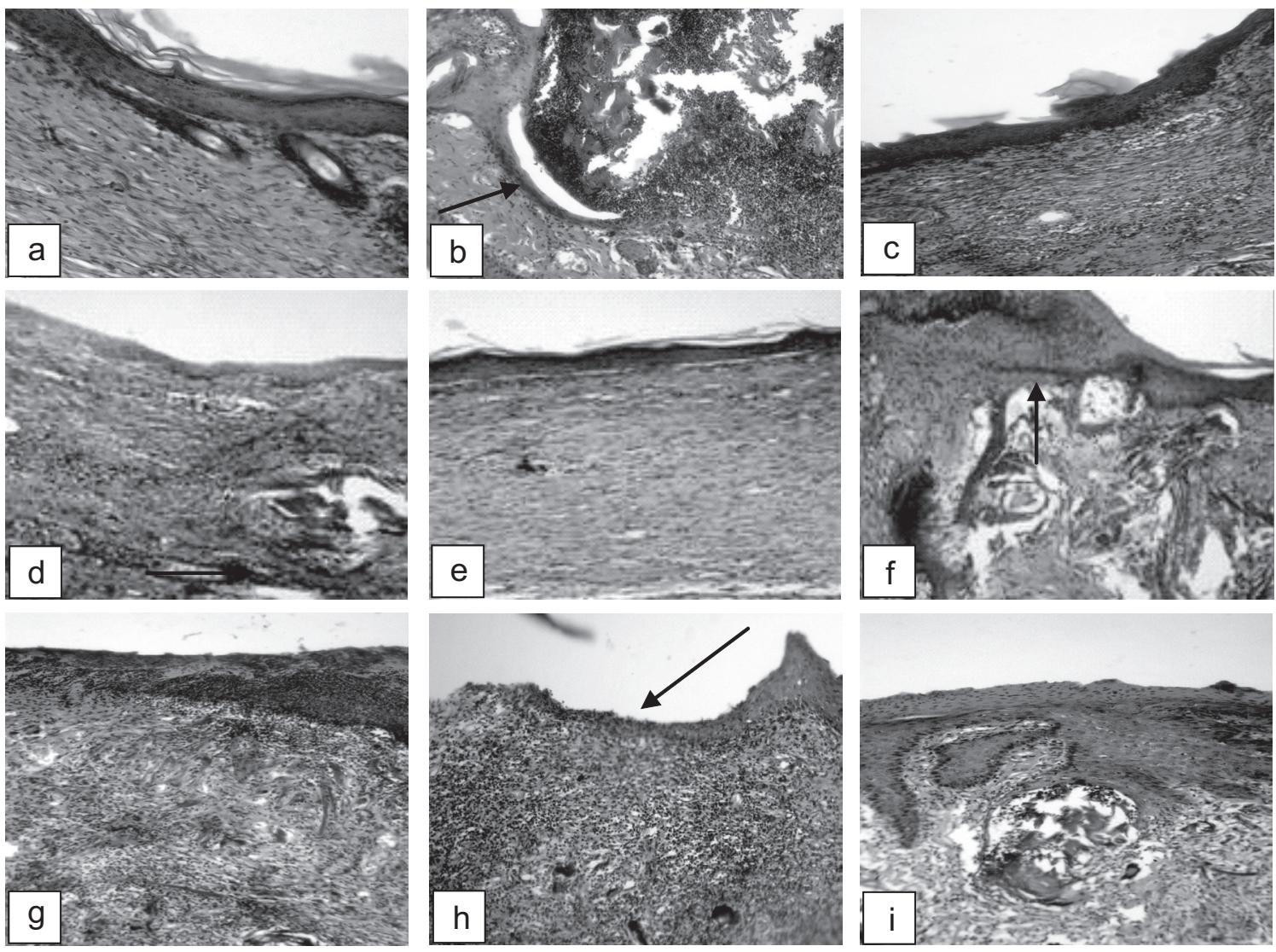

Fig. 2. The histological study of the skin of rats with purulent necrotic wounds treated with the gels under research on day 11 after infection. Notes: 1) The gel with glucosamine (gel 1), a - the absence of the ulcer defect, recovery of the epidermis, hair follicles, the fibrous tissue replaces the dermis ( $\times 250$ ); $\mathrm{b}$ - a small pustule, a visible marginal epithelialisation (arrow, $\times 100) ; 2$ ) the gel with silver nanoparticles (gel 2): $\mathrm{c}$ - under the regenerated epithelium there is a soft fibrous scar with foci of inflammatory infiltrates; $d$ - the site of destructive fibres with the altered tinctorial properties under the fibrous scar; 3 ) the gel with glucosamine and nanosilver (gel 3): $\mathrm{e}$ - complete healing of the former defect; $\mathrm{f}$ - the epithelial wedge penetrates the crust (arrow); 4) the reference drug: $g$ - the ulcerative defect is covered with the hemorrhagic-necrotic crust and filled with necrotic tissues; $h$ - a newly formed epithelial wedge (arrow) covering a very immature granulation; $\mathrm{i}$ - the signs of acanthosis and parakeratosis in the thickened epidermis, the isolated site of necrotic fibres. Haematoxylin-eosin. $x 100$.

are open ulcerative defects. The collagenic fibres of the reticular dermis of the sites located near the defect are damaged (Fig. 2 a, b). The rest $40 \%$ of cases the ulcer is large and deep, covered by a thick crust, it is filled about $2 / 3$ with the cellular detritus containing less degraded leukocytes. In the depths the initial signs of creation of the granulation tissue are observed. The rest of the rats had ulcerative defects.

After treatment of purulent necrotic wounds using the gel with silver nanoparticles (gel 2) in $60 \%$ of rats there is no defect of the skin on microslides. In the site of the former ulcer the epithelial layer is slightly thickened. The newly formed fibrous tissue has the high cell content; sometimes small accumulations of small white blood cells are observed in it. Sometimes there are sites of destructive fibres under the scar and the dermis on the neighbouring healthy areas of the skin in the underlying tissues (Fig. 2 c, d).

In the group of rats treated with the gel with silver nanoparticles and glucosamine (gel 3) in 40\% of the animals the ulcerative defect has been completely healed. In its place a soft scar is seen (Fig. 2 e, f). In $20 \%$ of the rats there is a small defect. In other $40 \%$ of the animals the open ulcerous defects that are large in size have been found; they are covered by a narrow scab, under which a significant amount of immature granulation tissue, or its small sites at the bottom are observed. In some rats there is cellular infiltration (varying by the intensity) of the complex of tissues underlying to the dermis with impregnations of a few giant cells and "petrified" fibres.

After treatment with the reference drug the complete healing of the defect is not observed in any rats. The ulcerative surface of some animals is covered by the crust other animals have a clean surface. In most cases the defect is filled with the immature granulation tissue, in which there are visible remains of died "petrified" fibres, giant cells. In some rats the marginal epithelisation of the surface is well visible (Fig. 2 g, h, i). In $20 \%$ of the animals there is an abscess in the deep layers of the defect. In the sites of the healthy skin that are marginal with ulcers there is the thickened epidermis with a visible acanthosis, parakeratosis, and in the dermis the isolated sites of damaged fibres with giant cells nearby can be observed. In the tissues surrounding the dermis there are visible cell infiltrates.

Thus, the gels with glucosamine or silver nanoparticles and their combination under study applied to animals with purulent necrotic wounds have better histological parameters of recovery of damaged tissues than those of the reference drug - "Dermazin" cream. By histological evaluation gel 2 (silver nanoparticles) and gel 3 (with silver nanoparticles and glucosamine) have revea- 
led the most positive effect on healing of the infected ulcers. However, by characteristics a newly formed tissue has the most complete character in animals treated with the sample of gel 3. It confirms the rationality of the combination with silver nanoparticles and glucosamine proposed and the absence of antagonism between the active ingredients. Consequently, by the effect on maturation and quality of the newly formed tissue when healing wounds the drugs under study can be arranged as follows: gel $3>$ gel $2>$ gel $1>$ "Dermazin" cream.

CONCLUSIONS

1. On the model of the infected wound in rats the histological studies have shown that all gels with glu- cosamine or silver nanoparticles and their combination contribute to healing of infected wounds more than those that heal naturally. By maturation and quality of a newly formed tissue in the wound the gels studied exceed the reference drug.

2. By histological evaluation a newly formed tissue has the most complete character in the wound of animals treated with sample 3 containing glucosamine with silver nanoparticles.

3. Therefore, for further pharmacological studies the combined gel containing glucosamine and silver nanoparticles is promising in order to develop a local drug of a new generation to treat infectious surface wounds.

\section{REFERENCES}

1. Бабушкина И.В. // Сарат. научн.-мед. журн. - 2011. - Т. 7, №2. - С. 530-534.

2. Методичні рекомендаиї̈ «Екпериментальне вивчення нових препаратів для місиевого лікування ран» / Л.В.Яковлєва, О.В.Ткачова, Я.О.Бутко, Ю.Б.Лар яновська. - Х., 2013. - 52 с.

3. Пат. №92307 UА, МПК А $61 \mathrm{~K}$ 9/06 (2006.01), А $61 \mathrm{~K}$ 33/38 (2006.01), A 61 P 17/02 (2006.01), A 61 P 31/02 (2006.01), А 61 Р 31/00. Фармацевтична композииія у формі гелю з наночастками срібла для лікування ран та запальних інфекиійних захворювань / С.Б.Патон, В.П.Черних, Б.О.Мовчан та ін. - Власники: Патон Б.С., Національний фармачевтичний університет. - № и201402559. Заявл.: 14.03.2014. Опубл.: 11.08.2014. - Бюл. №15.

4. Ткачова О.В., Лар'яновська Ю.Б., Яковлєва Л.В. // Фармакол. та лікарська токсикол. - 2012. - Т. 30, №5. - C. 67-72.

5. Туляков В.О., Зупанеиь К.О., Шебеко С. К. // Фармакол. та лікарська токсикол. - 2009. - Т. 9, №2. - С. 3-7.

6. Ускладнення ран та проиесу їх загоєння. Режим достуny: http://www.ukrainereferat.org/uaref-2746-2.html

7. Kieser D.C., Hammond C. // Adv. Skin Wound Care. - 2011. - №2. - P. 68-70.

8. Pastar I. Ramirez H., Stojadinovic O. et al. // Surgical Technol. International. - 2011. - №12. - P. 51-60.

9. Thomson Ch., Hassan I., Dunn K. // J. of Wound Care. - 2012. - №11. - P. 568-569.

\section{ГІСТОЛОГІЧНІ ДОСЛІДЖЕННЯ ВПЛИВУ ГЕЛІВ ІЗ НАНОЧАСТКАМИ СРІБЛА ТА ГЛЮКОЗАМІНОМ НА ЗАГОЄННЯ ІНФІКОВАНИХ РАН \\ Л.О.Булига, Я.О.Бутко, Ю.Б.Лар'яновська}

Ключові слова: гнійні рани; гель; наночастки срібла; глюкозамін; гістологія Пошук нових засобів для лікування гнійних ран залишається однією з актуальних проблем сучасної медицини. Більшість місцевих ранозагоювальних засобів на фрармацевтичному ринку України не відповідають усім медико-біологічним вимогам ефективного лікування ранового процесу, що потребує розширення їх номенклатури. Сучасні розробки присвячені використанню наночасток срібла для лікування ран, які мають ряд переваг: багаторівневий антибактеріальний ефрект, повільний розвиток резистентності, низький рівень токсичності, протизапальні та репаративні властивості. Метою цієї роботи було гістологічне дослідження впливу гелів із наночастками срібла та глюкозаміном на загоєння шкіри за умови гнійно-некротичної рани у щурів. Результати досліджень показали, що у тварини з ранами, яким наносили досліджувані гелі з глюкозаміном або з наночастками срібла та їх комбінація, мають гістологічні показники відновлення пошкоджених тканин кращі, ніж у препарату порівняння крему «Дермазин». Найбільш повноцінний характер мала новоутворена тканина у тварин, яким наносили зразок гелю з наночастками срібла та глюкозаміном, що підтверджує раціональність запропонованої комбінації та відсутність антагонізму між діючими речовинами. Отже, комбінований гель, що містить глюкозамін та наночастки срібла, є перспективним для подальшого фрармакологічного дослідження з метою розробки місцевого засобу нового покоління для лікування інфекційних поверхневих ран.

\section{ГИСТОЛОГИЧЕСКОЕ ИССЛЕДОВАНИЕ ВЛИЯНИЯ ГЕЛЕЙ, СОДЕРЖАЩИХ} НАНОЧАСТИЦЫ СЕРЕБРА И ГЛЮКОЗАМИНА, НА ЗАЖИВЛЕНИЕ ГНОЙНЫХ РАН Л.А.Булыга, Я.А.Бутко, Ю.Б.Ларьяновская

Ключевые слова: гнойные раны; гели; наночастицы серебра; глюкозамин, гистология Поиск новых препаратов для лечения гнойных ран остается одной из актуальных проблем современной медицины. Большинство местных ранозаживляющих средств на фрармацевтическом рынке Украины не отвечают всем медико-биологическим требованиям эффректив- 
ного лечения раневого процесса, что требует расширения их номенклатуры. Современные разработки посвящены использованию наночастиц серебра для лечения ран, которые имеют ряд преимуществ: многоуровневый антибактериальный эффрект, медленное развитие резистентности, низкий уровень токсичности, противовоспалительные и репаративные свойства. Целью этой работы было гистологическое исследование влияния гелей с наночастицами серебра и глюкозамином на заживление кожи в условиях гнойно-некротической раны у крыс. Результаты исследований показали, что у животных с ранами, которым наносили исследуемые гели с глюкозамином или наночастицами серебра и их комбинацию, имеются гистологические показатели восстановления поврежденных тканей лучше, чем у препарата сравнения крема «Дермазин». Наиболее полноценный характер имела новообразованная ткань у животных, которым наносили образец геля с наночастицами серебра и глюкозамином, что подтверждает рациональность предложенной комбинации и отсутствие антагонизма между действующими веществами. Итак, комбинированный гель, содержащий глюкозамин и наночастицы серебра, является перспективным для дальнейшего фрармакологического исследования с целью разработки местного средства нового поколения для лечения инфекционных поверхностных ран. 